\title{
Abu Cangkang Kerang Anadara granosa, Linnaeus 1758 (Bivalvia: Arcidae) sebagai Adsorben Logam Berat dalam Air Laut
}

\author{
Wisnu Satriyo Sudarmawan*, Jusup Suprijanto, Ita Riniatsih \\ Departemen IImu Kelautan, Fakultas Perikanan dan Ilmu Kelautan, Universitas Diponegoro \\ JI. Prof. H. Soedarto S.H, Tembalang, Semarang, Jawa Tengah 50275 Indonesia \\ *Corresponding author, e-mail : wisnusatriyo.wss98@gmail.com
}

\begin{abstract}
ABSTRAK: Kerang Darah merupakan komoditi ekonomis yang tersebar di seluruh wilayah perairan Indonesia, salah satunya adalah Perairan Demak. Adanya permintaan yang tinggi pada daerah demak dari hasil survey DKP Kabupaten Demak pada tahun 2018 dapat menimbulkan terjadinya limbah cangkang yang cukup banyak. Melalui pendekatan teknologi yang tepat, limbah cangkang kerang tersebut dapat diolah menjadi abu cangkang. Berdasarkan komposisi senyawa kimia abu cangkang mengandung $\mathrm{CaO}$ cukup tinggi sehingga abu cangkang berpotensi untuk menjerap logam berat. Materi yang digunakan dalam penelitian adalah abu cangkang hasil olahan dari limbah cangkang sisa produksi kerang darah. Metode eksperimental laboratoris dilakukandalam penelitian yaitu dengan mengontakkan secara langsung logam dan abu cangkang kerang dara (Anadara granosa) dengan pengaruh variasi jenis logam berat dengan analisis spektroskopi serapan atom (SSA). Penyerapan yang optimal terjadi pada logam berat Mangan (Mn) konsentrasi awal 0,103 mg/L menjadi <0,001 dan kontak waktu 24 jam daya serap sebesar $100 \%$. Dapat disimpulkan bahwa pada abu cangkang cukup baik dalam penyerapan logam berat Besi (Fe), Mangan (Mn), Seng ( $\mathrm{Zn})$ di air laut perairan Morosari Demak karena dalam proses menghilangkan logam berat dengan struktur $\mathrm{CaO}$ disebut pertukaran ion dipengaruhi oleh beberapa faktor jenis adsorben yang digunakan, luas permukaan adsorben, dan konsentrasi zat yang di penjerapan.
\end{abstract}

Kata kunci: Adsorpsi; Abu Cangkang; Anadara granosa; Logam Berat

\section{Ash of Anadara granosa Linnaeus 1758 (Bivalvia: Arcidae) as A Heavy Metal Adsorbent in Sea Water}

ABSTRACT: Blood cockle are economic commodities that are spread throughout the territorial waters of Indonesia, one of which is the Demak waters. The high demand in the Demak area from the results of DKP survey in 2018 can causing a lot of cockle shell waste. Through the right technological approach, the waste is processed into blood cockle shell ash. Based on the chemical composition of shell ash containing $\mathrm{CaO}$ in the shell is high enough so the ash has potential to absorb heavy metals. The material used is the blood cockle shell ash that processed from waste shell from the production of blood cockle. The experimental laboratory method was carried out in this research, by directly contacting metal and blood cockle shell ash (Anadara granosa) with the influence of variations in heavy metal types by atomic absorption spectroscopy (AAS) analysis. Optimal absorption occurs in the heavy metal Manganese (Mn) initial concentration of $0.103 \mathrm{mg} / \mathrm{L}$ to $<0.001$ and 24-hour contact time absorption of $100 \%$. It can be concluded that the shell of the product itself has not been efficient in carrying out all the absorption of heavy metals in the sea water samples of Morosari Demak waters because in the process of removing heavy metals with $\mathrm{CaO}$ structures is influenced by the type of adsorbent used, the surface area of the adsorbent, and the concentration of in absorption.

Keywords: Ash shells; Absorption; Anadara granosa; heavy metals 


\section{PENDAHULUAN}

Perairan Morosari yang berada di antara Semarang sampai Demak, merupakan daeral fishing ground bagi nelayan tradisional Semarang dan Demak untuk menangkap kerang udang, rajungan maupun ikan (Suryono dan Rochaddi, 2017). Salah satu biota dengan potensPerairan Morosari yang berada di antara Semarang sampai Demak, merupakan daeral fishing ground bagi nelayan tradisional Semarang dan Demak untuk menangkap kerang udang, rajungan maupun ikan (Suryono dan Rochaddi, 2017). Salah satu biota dengan potensi tinggi tersebut adalah Kerang Darah / (Andara granosa) sebagai makanan konsumsi dan bahan baku souvenir. Produksi kerang darah cukup besar pada tahun 2010 mencapai 34.482 Ton dengan rata-rata peningkatan produksi tahun 2000 - 2010 sebesar 5,18\% tiap tahun (Pemerintah RI, 2011). Perairan Demak merupakan salah satu kawasan penghasil kerang terbesar di pesisir Jawa Tengah. Terjadinya permintaan akan Kerang Darah yang cukup tinggi di dasari dari hasil survey Dinas Kelautan dan Perikanan Kabupaten Demak (2018) menyatakan bahwa Kabupaten Demak menghasilkan kerang sebanyak $310.798,91 \mathrm{~kg}$ selama tahun 2018. Kegiatan utama nelayan Demak berpenghasilan cukup signifikan adalah usaha menangkap kerang dan pembesaran benih Kerang Darah ( $A$. granosa) atau biasa disebut kerang Jae yang dilakukan oleh Kelompok Nelayan Tambak Kerang Mutiara Sari. Hasil wawancara survei penulis terhadap Bapak Sadam dan Bapak Sarwani selaku Kelompok nelayan Mutiara Sari, masing - masing anggota memiliki lahan tambak $\pm 2000 \mathrm{~m}^{2}$ yang dipanen setiap minggu 2 kali dengan penghasilan pada per hari masa panen 1 kwintal setiap tambak dengan nilai rupiah Rp, 10.000,00 tiap 1 Kilogram. Setiap 1 Kilogram hasil panen Kerang Darah mempunyai perbandingan hasil daging dan cangkang sebanyak 1:4 sehingga banyak menghasilkan limbah yang mengganggu karena belum ada pengelolaan hasil limbah cangkang kerang.

Menurut penelitian yang dilakukan No et al., (2003), menyatakan bahwa senyawa kimia yang terkandung dalam cangkang kerang adalah Kitin, kalsium karbonat, kalsium hidrosiapatit dan kalsium posfat. Sebagian besar cangkang kerang mengandung kitin. Kitin merupakan suatu polisakarida alami yang memiliki banyak kegunaan, seperti bahan pengkelat, pengemulsi dan adsorben. Adsorpsi adalah proses penggumpalan substansi terlarut dalam larutan oleh permukaan zat penyerap yang membuat masuknya bahan dan mengumpul dalam suatu zat penyerap. Pada adsorpsi ada yang disebut adsorben dan adsorbat. Adsorben adalah zat penyerap, sedangkan adsorbat adalah zat yang diserap (Giyatmi, 2008). Adsorben merupakan zat padat yang dapat menyerap komponen tertentu dari suatu fase fluida. Adsorben biasanya menggunakan bahanbahan yang memiliki pori-pori sehingga proses adsorpsi terjadi di pori-pori atau pada letakletak tertentu di dalam partikel tersebut. Pada umumnya pori-pori yang terdapat di adsorben biasanya sangat kecil, sehingga luas permukaan dalam menjadi lebih besar daripada permukaan luar. Pemisahan terjadi karena perbedaan bobot molekul atau karena perbedaan polaritas yang menyebabkan sebagian molekul melekat pada permukaan tersebut lebih erat daripada molekul lainya (Saragih, 2008).

Semarang dan Demak merupakan wilayah yang terletak di pantai Utara Jawa. Kawasan pesisir tidak hanya dimanfaatkan oleh masyarakat sebagai tempat untuk mencari penghasilan, akan tetapi juga dimanfaatkan oleh industri dan masyarakat setempat sebagai tempat pembuangan limbah. Limbah cenderung mengandung bahan kimia beracun dan berbahaya. Industri dapat menghasilkan limbah logam berat $\mathrm{Cd}, \mathrm{Cr}, \mathrm{Pb}, \mathrm{Fe}, \mathrm{Zn}$ dan logam berat lainnya (Yulianto et al., 2006). Logam berat tersebut merupakan logam berat yang banyak digunakan di berbagai industri diantaranya yaitu industri cat, tinta, petrokimia hulu, korek api, soda kaustik, pelapisan logam, industri galvanis, pembersihan karat, pengolahan bijih besi, emas, tembaga, dan industri baterai (Pemerintah RI, 2013). Bahan-bahan buangan yang bersifat racun yang masuk ke perairan akan menurunkan kualitas air yaitu berubahnya sifat-sifat fisika dan kimia perairan. Hal ini dapat membahayakan kehidupan organisme perairan terutama hewan benthos karena pergerakannya yang terbatas (sessile) dan sifat hidupnya yang relatif menetap di dasar perairan sehingga bila terjadi pencemaran akan sulit untuk menghindar (Supriharyono, 2002). Namun semakin berkembangnya kawasan industri di daerah pesisir, pencemaran limbah yang dihasilkan 
dari kegiatan industri juga semakin banyak, kondisi ini dapat mengancam ekosistem yang ada di kawasan pesisir dan secara tidak langsung juga mengancam kesehatan manusia karena sifat logam berat yang tidak bisa terurai dan mudah terakumulasi (Mokoagouw, 2008).

Pencemaran oleh logam berat $\mathrm{Pb}, \mathrm{Cu}$, dan $\mathrm{Zn}$ sangat memungkinkan terjadi jika melihat penggunaannya yang cukup luas. Pencemaran yang terjadi dapat diketahui tidak hanya berdasarkan kandungan air limbah tetapi dapat juga berdasarkan pemantauan terhadap kualitas air, sedimen maupun biota perairan. Pemantauan kadar logam berat pada Teluk Jakarta menunjukkan bahwa sedimen mengandung 0,25 - 69,22 mg/l logam timbal ( $\mathrm{Pb}$ ) (Rochyatun dan Rozak, 2007) sedangkan penelitian Amien dan Iromo (2010) menunjukkan kandungan $\mathrm{Pb}$ yang cukup tinggi pada perairan Tarakan, Kalimantan Timur mencapai 0,2787 mg/l dimana baku mutu maksimal sebesar 0,05 mg/l (Pemerintah Rl, 2004). Kandungan $\mathrm{Cu}$ pada sungai Sayung Kabupaten demak pada tahun 2010 berkisar antara 0,01-0,05 mg/ dimana baku mutu maksimal sebesar $0,02 \mathrm{mg} / \mathrm{l}$ (Pemerintah RI, 2001). Kandungan Zn yang cukup tinggi juga terjadi pada aliran Kali Garang Semarang yang mencapai 0,611-1,420 mg/l (Rohman et al., 2010) dimana baku mutu air sungai yang dapat dimanfaatkan sebagai kegiatan perikanan maksimal kandungan $\mathrm{Zn}$ sebesar $0,05 \mathrm{mg} /$ (Pemerintah RI, 2001). Kandungan logam berat Fe dalam air di Muara Sungai Morosari dan Sungai Gonjol, Kec. Sayung, Kab. Demak tertinggi dalam air terjadi pada Bulan Juli 2010 di Sungai Morosari (9,64 mg/l) dan di Sungai Gonjol (3.045 mg/l) (Firmansyaf, 2013) dimana baku mutu air sungai yang dapat dimanfaatkan sebagai kegiatan perikanan maksimal kandungan Fe sebesar 0,5 mg/l (Pemerintah RI, 2001). Kondisi logam yang ditemukan melebihi baku mutu yang dipersyaratkan dapat mengakibatkan dampak bagi kesehatan manusia.

Penyebab utama logam berat menjadi bahan pencemar berbahaya yaitu logam berat tidak dapat dihancurkan (non degradable) oleh organisme hidup di lingkungan dan terakumulasi ke lingkungan, terutama mengendap di dasar perairan membentuk senyawa kompleks bersama bahan organik dan anorganik secara adsorbsi dan kombinasi (Pagoray, 2001). Limbah industri merupakan sumber pencemaran yang potensial bagi perairan laut Sebagai contoh adalah Minamata. industri kimia yang beroperasi di sekitar Teluk Minamata ini membuang limbah yang mengandung merkuri ke perairan teluk. Ibu-ibu yang mengkonsumsi makanan laut (sea food) yang diperoleh dari Teluk Minamata yang tercemar oleh merkuri melahirkan anak-anak cacat bawaan. Selain itu kasus keracunan kadmium juga terjadi di Jepang yang terkenal dengan penyakit itai-itai dengan gejala sakit pada tulang dan keroposnya tulang (Effendi, 2000).

Berdasarkan hasil penelitian yang telah dilakukan oleh Maryam (2006) bahwa serbuk cangkang kerang hasilnya cukup baik untuk menjerap logam berat maka penelitian ini mempunyai tujuan untuk melihat potensi cangkang abu kerang sebagai. adsorben alternatif yang ramah lingkungan. Komposisi abu cangkang kerang terdiri atas senyawa yaitu 7,88\% $\mathrm{SiO}_{2} ; 1,25 \% \mathrm{Al}_{2} \mathrm{O}_{3}$; 0,03\% $\mathrm{Fe}_{2} \mathrm{O}_{3} ; 66,70 \% \mathrm{CaO}$; dan 22,28\% MgO (Maryam, 2006). Berdasarkan komposisi kimia tersebut kandungan $\mathrm{CaO}$ pada suatu cangkang cukup tinggi sehingga abu cangkang berpotensi sebagai adsorben. Kalsium oksida merupakan senyawa kimia yang banyak digunakan untuk dehydrator, pengering gas dan pengikat $\mathrm{CO}_{2}$ pada cerobong asap. Kalsium oksida merupakan senyawa turunan dari senyawa kalsium karbonat $\left(\mathrm{CaCO}_{3}\right)$. Senyawa ini mampu mengikat air pada etanol karena bersifat dehydrator sehingga cocok digunakan sebagai adsorben (Retno et al., 2012). Penelitian dilakukan pada skala laboratorium yang bertujuan untuk melihat hubungan sebab-akibat antara dua faktor atau lebih yang sengaja dilakukan oleh peneliti untuk melihat potensi abu cangkang kerang dalam menyerap logam berat pada sampel uji air laut dengan perlakuan pengaruh sebelum dan sesudah pemberian abu cangkang.

\section{MATERI DAN METODE}

Materi yang digunakan adalah cangkang dan sampel air laut sebagai bahan uji dalam percobaan ini seperti yang telah dilakukan oleh (Maryam, 2006). Metode penelitian yang digunakan adalah metode eksperimental laboratoris yaitu penelitian yang dilakukan dengan tujuan pengujian hubungan sebab-akibat antara dua faktor atau lebih yang sengaja dilakukan oleh peneliti untuk melihat pengaruh sebelum dan sesudah pemberian abu cangkang dengan berbagai jenis percobaan logam berat yang berbeda, yaitu: Besi (Fe), Mangan (Mn) dan Seng (Zn). Pengambilan sampel pada penelitian ini dilakukan secara bertahap mulai dari pengumpulan 
informasi lokasi, persiapan penelitian, pengambilan data di lapangan dan pengolahan data. Sampel yang digunakan pada penelitian ini adalah sampel air laut yang di ambil dari Perairan Morosari Demak menggunakan botol plastik $250 \mathrm{~mL}$ sebanyak dua ali(SNI 6989.57.2008). Botol sampel ditutup rapat dan dimasukkan kedalam coolbox. Pengambilan sampel air dilakukan Uji AAS di Laboratorium Balai Besar Teknologi Pencegahan Pencemaran Industri Semarang.

Proses pembuatan abu cangkang yaitu diawali dengan mencuci dan mengeringkan limbah cangkang, kemudian cangkang kerang kemudian dihaluskan menggunakan mesin penggiling atau di pecah kecil - kecil dengan ukuran $\pm 1 \mathrm{~cm}$. Cangkang kerang yang sudah bersih dan kering di masukan ke dalam wadah krusibel yang kosong ke dalam oven selama 30 menit pada suhu $105^{\circ} \mathrm{C}$ hingga beratnya konstan. Krusibel yang sudah diketahui beratnya diisi dengan sampel lalu ditimbang kembali, kemudian dilakukan pengabuan dalam furnace dengan suhu $800^{\circ} \mathrm{C}$ dengan waktu kalsinasi 360 menit sampai jadi abu. Sampel abu didinginkan dalam desikator selama 30 menit, berat abu cangkang yang sudah dingin kemudian ditimbang dan diayak dengan ayakan 200 mesh / $0.074 \mathrm{~mm}$ (Afranita et al., 2014).

Menurut Asleni (2013), kandungan abu cangkang kerang darah ditentukan dengan cara menimbang berat krusibel kosong hingga beratnya konstan. Setelah konstan krusibel diisi dengan cangkang kerang darah sesuai dengan ukuran krusibel, selanjutnya beratnya di timbang ( $\left.\mathrm{W}_{1}\right)$. Kemudian krusibel yang berisi cangkang kerang darah dimasukkan ke dalam furnace dan dipanaskan pada suhu $800^{\circ} \mathrm{C}$ dengan waktu kalsinasi 4 jam. Setelah dipanaskan, berat krusibel ditimbang kembali $\left(\mathrm{W}_{2}\right)$. Sehingga dihasilkan kandungan abu cangkang kerang darah dengan menggunakan rumus sebagai berikut :

$$
\text { Kandungan abu }(\%)=\frac{\mathrm{W}_{1}}{\mathrm{w}_{2}} \times 100 \%
$$

Keterangan : $\mathrm{W}_{1}=$ Berat cangkang + krusibel $(\mathrm{gr}) ; \mathrm{W}_{2}=$ Berat abu + krusibel $(\mathrm{gr})$

Menurut Afranita et al. (2014), komposisi abu cangkang kerang yang dimasukan ke gelas beaker sebanyak $0,5 \mathrm{gr}$ dalam $20 \mathrm{ml}$ larutan sampel. Sedangkan penelitian ini menggunakan $25 \mathrm{gr}$ sampel abu cangkang dalam $1000 \mathrm{ml}$ air laut. Kemudian campuran larutan diaduk menggunakan magnetic stirrer dengan kecepatan 200 putaran per menit selama 30 menit dan didiamkan selama 24 jam (Yuliusman and Adelina 2010). Selanjutnya larutan disaring dengan kertas saring bebas logam (whattman 42) dan filtratnya dianalisis dengan spektroskopi serapan atom atau AAS.

Pengukuran daya absorbansi dangan metode AAS dilakukan dengan mengambil filtrat bagian atas larutan lalu dilakukan uji kandungan logam berat untuk mengukur daya absorbansi dengan Metode Atomic Absorption spectrophotometric (AAS). Perhitungan daya serap abu cangkang kerang terhadap kadar logam berat yang terdapat pada sampel air yang di gunakan sebagai media polutan untuk dilakukan percobaan melihat kandungan sebelum dan sesudah pemberian abu cangkang kerang sebagai adsorben alternatif dengan menggunakan persamaan sebagai berikut:

$$
\text { Daya Serap }=\frac{(\text { Larutan Sebelum-Larutan Sesudah })}{\text { Larutan Sebelum }} \times 100 \%
$$

Keterangan $:$ Larutan Sebelum $=$ Air Laut (gr); Larutan Sesudah = Air Laut + Abu Cangkang (gr)

Analisis data dari penyerapan abu cangkang yang diperoleh dari hasil penelitian berupa persentase penyerapan kadar logam berat. Pengolahan data menggunakan program Microsoft Office Excel 2016. Program Microsoft Excel 2016 digunakan untuk mengetahui jumlah dan persentase penyerapan kadar logam berat yang digambarkan dalam bentuk grafik. Data tersebut kemudian disampaikan secara deskriptif.

\section{HASIL DAN PEMBAHASAN}

Pembentukan kalsium oksida $(\mathrm{CaO})$ dalam penelitian ini dapat dilihat dari perubahan berat sampel sebelum dan sesudah kalsinasi dengan asumsi bahwa telah terjadi reaksi dekomposisi 
sesuai dengan persamaan reaksi (1). Besarnya perubahan berat abu pada suhu $800^{\circ} \mathrm{C}$ selama 4 jam dengan hasil sebelum dan sesudah kalinansi dari 48,0064 gr menjadi 47,4937 gr.

Hasil analisis adsorpsi logam berat berbeda dengan abu cangkang kerang darah pada yang dilakukan pada proses kalsinasi suhu $800^{\circ} \mathrm{C}$ dengan variasi waktu kalsinasi dari 4 jam yang bertujuan untuk mendapatkan kerangka $\mathrm{CaO}$ yang optimal. Hasil kemampuan penyerapan logam berat pada perairan tersebut dapat dilihat pada Tabel 1.

Hasil nilai rata-rata konsentrasi logam berat di air jika dibandingkan dengan baku mutu yang dikeluarkan oleh Kementrian Negara Lingkungan Hidup No. 51 tahun 2004 yaitu nilai kandungan logam berat Besi ( $\mathrm{Fe}$ ) awalnya $0,124 \mathrm{mg} / \mathrm{L}$ mengalami penurunan menjadi $0,076 \mathrm{mg} / \mathrm{L}$ akan tetapi tidak termasuk tercemar bila nilai dibawah $0,5 \mathrm{mg} / \mathrm{L}$, nilai kandungan logam berat Mangan (Mn) awalnya $0,103 \mathrm{mg} / \mathrm{L}$ mengalami penurunan menjadi $0,001 \mathrm{mg} / \mathrm{L}$ akan tetapi tidak termasuk tercemar bila nilai dibawah 0,5 mg/L, nilai kandungan logam berat Seng ( $\mathrm{Zn})$ awalnya 0,183 mg/L mengalami penurunan menjadi $0,01 \mathrm{mg} / \mathrm{L}$ akan tetapi tidak termasuk tercemar bila nilai dibawah $0,05 \mathrm{mg} / \mathrm{L}$. Pengujian kandungan logam juga dilakukan pada Kadmium (Cd), Kromium total (Cr), Nikel (Ni), Tembaga ( $\mathrm{Cu}$ ), dan Timbal $(\mathrm{Pb})$ yang menunjukan hasil bahwa tidak ada perubahan yang signifikan. Hal ini terjadi karena spesifikasi alat laboratorium AAS (Atomic Absorption Spectrofotometer) memiliki nilai batas limit.

Kemampuan daya serap abu cangkang kerang terhadap logam berat yang dilihat dari variasi logam berat terlihat bahwa pemberian abu mempengaruhi daya serap logam berat. Berdasarkan hasil penelitian diperoleh kemampuan daya serap abu cangkang kerang terhadap penyerapan logam $25 \mathrm{~g} / \mathrm{L}$ dengan waktu kontak optimum 24 jam terlihat bahwa pada logam Besi (Fe) diperoleh daya serap sebesar $38,7 \%$, Seng (Zn) diperoleh daya serap sebesar 94,5\%. Penyerapan optimal diperoleh pada Logam berat Mangan (Mn) Sebesar $100 \%$ yang dapat dilihat pada Tabel 1.

Namun terlihat pada hasil logam berat besi (Fe) dan Seng ( $\mathrm{Zn}$ ) terjadi penurunan dikarenakan perbedaan jenis adsorben logam. Menurut Alkharki et al., (2008) kapasistas penjerapan dapat dipengeruhi oleh jenis adsorben berbeda yang digunakan, luas permukaan adsorben, dan konsentrasi zat yang di penjerapan. Ukuran partikel yang semakin kecil akan menyebabkan semakin luasnya permukaan kontak yang mempengaruhi proses penjerapan. Menurut penelitian Budin et al., (2014), abu cangkang kerang dara dapat menyerap logam berat $\mathrm{Cr}$ sebesar $97,45 \%$ faktor yang mempengaruhi proses bio-adsorpsi dalam penyerapan logam berat meliputi massa adsorben, jenis adsorben yang digunakan, dan adanya padatan tersuspensi lainnya dalam perairan.

Ukuran partikel dapat mempengaruhi daya penjerapan abu cangkang terhadap logam berat. Semakin besar ukuran partikel maka kecepatan penjerapan logam akan meningkat Faktor yang dapat mempengaruhi proses adsorpsi adalah jenis adsorben, macam zat yang diadsorpsi, konsentrasi zat, luas permukaan adsorben, dan temperatur saat proses berlangsung (Asleni, 2013). Kapasistas penjerapan dapat dipengeruhi oleh jenis adsorben yang digunakan, luas permukaan adsorben, dan konsentrasi zat yang di penjerapan (Alkharkhi et al., 2008). Selain itu, kapasitas penjerapan juga dipengaruhi oleh konsentrasi larutan ion logam yang digunakan dan bentuk kitosan yang digunakan sebagai penyerap. Ukuran partikel yang semakin kecil akan menyebabkan semakin luasnya permukaan kontak yang mempengaruhi proses penjerapan. Ukuran partikel dapat mempengaruhi daya penjerapan abu cangkang terhadap logam berat. Semakin besar ukuran partikel maka kecepatan penjerapan logam akan meningkat.

Tabel 1. Hasil analisis kemampuan penyerapan adsorben abu cangkang kerang terhadap variasi logam berat dengan waktu kontak 24 jam pada perairan air laut Morosari Kabupaten Demak.

\begin{tabular}{lllll}
\hline Parameter Kadar Logam Berat (mg/L) & Sebelum & Sesudah & Baku Mutu & Daya Serap (\%) \\
\hline Besi (Fe) & 0,124 & 0,076 & 0,5 & 38,7 \\
Mangan (Mn) & 0,103 & $<0,001$ & 0,5 & 100 \\
Seng (Zn) & 0,183 & 0,01 & 0,05 & 94,5 \\
\hline
\end{tabular}

Sumber : Ket. Baku Mutu Air Laut (Keputusan No.51/MENKLH/2004) 
Hasil penelitian dari kemampuan daya serap abu cangkang kerang diperoleh hasil sebelum dan sesudah pemberian abu cangkang dengan berbagai jenis penggunaan logam berat yang berbeda, yaitu: Besi (Fe), Mangan (Mn) dan Seng (Zn).

Hasil nilai rata - rata daya serap logam berat yaitu pada logam berat Besi berat Besi $(\mathrm{Fe})$ pada abu cangkang $A$. Granosa adalah 38,7\% sedangkan penelitian Zustriani (2019) pada Abu Biji Pepaya adalah 58,8\% jadi dapat disimpulkan abu Biji Pepaya lebih baik dari pada abu cangkang A. Granosa. Kandungan nilai daya serap pada penelitian logam berat Seng (Mn) dan Seng ( $\mathrm{Zn})$ adalah $100 \%$ dan $94,5 \%$ sedangkan penelitian Harahap et al. (2017) dan Wahyudianto (2016) pada abu Sekam Padi dan abu cangkang A. Granosa adalah $54 \%$ dan $27,7 \%$ jadi dapat disimpulkan abu cankang $A$. Granosa pada penelitian lebih baik dari pada abu Sekam Padi dan abu cangkang $A$. Granosa. Pengujian kandungan logam berat pada Besi (Fe), Mangan (Mn) dan Seng $(\mathrm{Zn})$ menunjukan hasil perubahan yang signifikan hal ini karena dipengaruhi oleh beberapa faktor jenis adsorben yang digunakan, luas permukaan adsorben, dan konsentrasi zat yang di penjerapan (Alkharki et al., 2018).

Berdasarkan hasil penelitian yang telah dilkukan oleh Maryam (2006) bahwa serbuk cangkang kerang hasilnya cukup baik untuk menjerap logam berat karena memiliki $66,70 \% \mathrm{CaO}$. Hal ini juga dijelaskan Pahlevi (2015) karena abu cangkang kerang dara memiliki diameter pori kerangka Cao sebesar $17.37 \mathrm{~m} / \mathrm{g}$ sedangkan ukuran jari- jari ion Cu2* (0,69 A) (Sukardjo, 1992) lebih kecil dan dibandingkan juga ukuran jari- jari ion Sn2 (0,93 A) (Achmad, 1992) memiliki hasil lebih kecil. Menurut Khan (2016), pada Identifikasi morfologi permukaan adsorben cangkang kerang Darah (Anadara Granosa) untuk mengetahui bagaimana pori-pori dari adsorben ditunjukkan dengan hasil analisis Scanning Electron Microscopy (SEM) dan untuk mengetahui jenis atom yang ada di permukaan adsorben digunakan analisis Energy Dispersive Spectroscopy (EDS) terlihat pada morfologi permukaan adsorben tanpa aktivasi masih terdapat banyak pengotor sehingga pori-pori adsorben tertutup. Zat pengikat logam (Chelating agent / APDC I amonium pirolidin ditiokarbonat) dapat mengikat logam dalam bentuk ikatan kompleks. Ion-ion logam dapat terlepas dari ikatan kompleksnya karena hidrolisis dan degradasi ion logam bebas mudah bereaksi dan pengikat logam akan mengikat ion logam (Winarno, 2004).

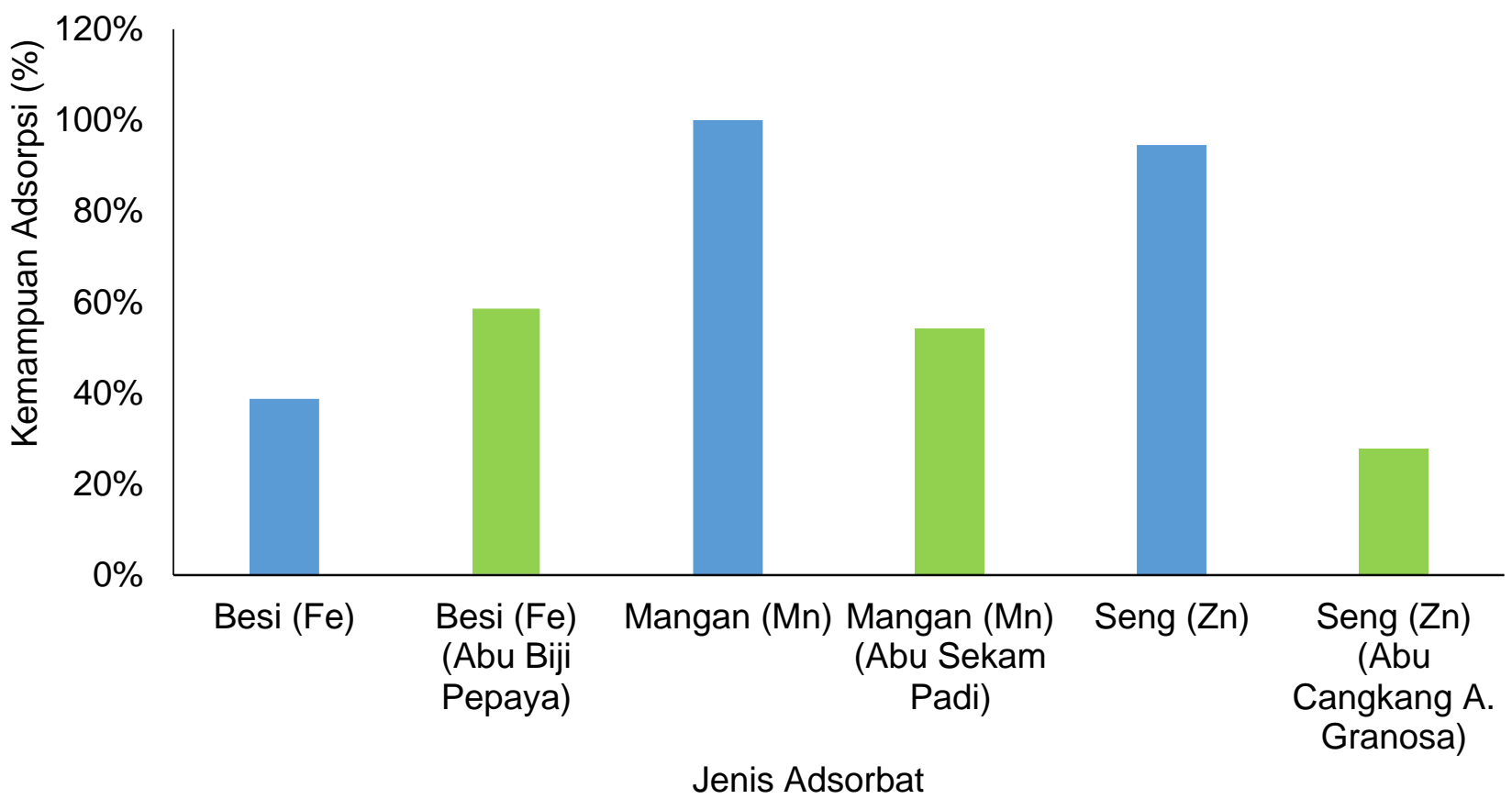

Gambar 2. Hasil Kemampuan Daya Serap Abu dari Cangkang Kerang dengan ion Logam Fe, Mn, dan Zn. 


\section{KESIMPULAN}

Berdasarkan hasil penelitian, dapat disimpulkan bahwa abu cangkang andara granosa cukup baik dalam penjerapan terhadap logam berat di perairan morosari demak. Nilai daya serap sesudah pemberian abu cangkang pada logam berat Mangan (Mn) ,Seng (Zn) ,Besi (Fe) adalah $100 \%, 94,5 \%, 38,7 \%$ dalam proses menghilangkan logam berat dengan struktur CaO disebut pertukaran ion dipengaruhi oleh beberapa faktor jenis adsorben yang digunakan, luas permukaan adsorben, dan konsentrasi zat yang di penjerapan.

\section{DAFTAR PUSTAKA}

[FAO] Fisheries and Aquaculture Organization. 2009. Anadara granosa (Linnaeus, 1758). Achmad, H. 1992. Kimia Unsur dan Radiokimia. PT. Citra Aditya Bakti, Bandung.

Afranita, G., Anita, S., \& Hanifah, T.A. 2014. Potensi Abu Cangkang Kerang Darah (Anadara Granosa) sebagai Adsorben Ion Timah Putih. Jurnal Online Mahasiswa Fakultas Matematika dan IImu Pengetahuan Alam Universitas Riau, 1(1):1-5

Alkharkhi, A., Norli, I. \& Azhar, M. 2008. Assesment of Arsenic and Heavy Metal Contents in Cockles (Anadara granosa) Using Multivariate Statistical Techniques. Journal of Hazardous Materials, 150:783-789.

Asleni. Itnawita. Kartika, G.F. 2013 .Potensi Abu Cangkang Kerang Darah (Anadara granosa) Dengan Variasi Waktu Kalsinasi Sebagai Adsorben Ion $\mathrm{Cu}^{2+}, \mathrm{Sn}^{2-}, \mathrm{CN}^{-}$dan $\mathrm{NO}^{3-}$. Jurnal Kimia Analitik.

Budin, K., Subramaniam, Y., Tair, R. \& Ali, S.M., 2014. The ability of crab and cockle shell to adsorb lead and chromium from industrial effluent. IOSR Journal of Environmental Science, Toxicology and Food Technology, 8:4-6.

Dinas Kelautan Dan Perikanan Kabupaten Demak. 2018. Statistik Perikanan Tangkap Kabupaten Demak. Dinas Kelautan dan Perikanan, Kabupaten Demak.

Effendi, H. 2000. Telahan Kualitas Air: Bagi Pengelolaan Sumberdaya dan Lingkungan Perairan. Penerbit Kanisius, Yogyakarta.

Firmansyaf, D., Yulianto, B., \& Sedjati, S. 2013. Studi Kandungan Logam Berat Besi (Fe) Dalam Air, Sedimen Dan Jaringan Lunak Kerang Darah (Anadara Granosa Linn) Di Sungai Morosari Dan Sungai Gonjol Kecamatan Sayung, Kabupaten Demak. Journal of Marine Research, 2(2):45-54

Giyatmi, 2008, Penurunan Kadar Cu,Cr dan Ag Dalam Limbah Cair Industri Perak di Kotagede Setelah Diadsorpsi Dengan Tanah Liat Dari Daerah Godean, Yogyakarta: Seminar Nasional SDM Teknologi Nuklir.

Harahap, A.D.H., Verantika, F., Fahmi, N.Y. \& Tanjung, A.P., 2017, January. Penyerapan Ion Logam Mangan (Mn) menggunakan Adsorben dari Sekam Padi Hasil Aktivasi dengan Asam Sitrat. In Prosiding Seminar Nasional Pascasarjana Unsyiah.

Khan, T.A., K.K. Peh, dan H.S. Chang. 2016. Reporting Degree of Deacetylation Values of Chitosan: The Influence of Analytical Methods, 5(3): 205-212.

Maryam, S. 2006. Pengaruh Serbuk Cangkang Kerang Sebagai Filter Terhadap Sifat - Sifat dari Mortar. Skripsi. MIPA. USU.

Mokoagouw, D. 2008. Indeks Keanekaragaman Biota Perairan sebgai Indikator Biologis Pencemaran Logam Berat di Perairan Pantai Bitung, Sulawesi Utara. Ekoton, 8(2):31-40.

No. H.K., Lee, S.H., Park, N.Y. \& Meyer, S.P. 2003. Comparison of Phsycochemical Binding and Antibacterial Properties of Chitosans prepared Without and With Deprotei Ization Process. Journal of Agriculture and Food Chemistry, 51:7659-7663.

Pagoray, H. 2001. Kandungan Merkuri dan Kadmium Sepanjang Kali Donan Kawasan Indutri Cilacap. Frontir. 33:1-9.

Pahlevi, M.R., Nurhayati \& Sofia, A. 2015. Variasi Berat Katalis dan Suhu Reaksi Transesterifikasi Crude Palm Oil Menggunakan Katalis Cangkang Kerang Darah Kalsinasi $800^{\circ} \mathrm{C}$. Jurnal Online Mahasiswa Fakultas Matematika dan IImu Pengetahuan Alam Universitas Riau. 2(1):186-191. 
Retno, D., Agus, P., Rizki, S. \& Wulandari, N., 2012. Pembuatan Ethanol Fuel Grade dengan Metode Adsorbsi Menggunakan Adsorbent Granulated Natural Zeolite Dan Cao. Simposium Nasional RAPI XI FT UMS-2K012. Teknik Kimia. Fakultas Teknik. Universitas Sebelas Maret.

Rochyatun, E. \& Rozak, A., 2007. Pemantauan Kadar Logam Berat dalam Sedimen di Perairan Teluk Jakarta. Makara Sains, 11(1):28-36.

Rohman, T., Syarifudin \& Zaman, B., 2010. Model Cemaran Seng (Zn) di Perairan Sungai dengan Metode Upwind dan Metode Quicktest berdasarkan Pembaganan Abbot-Ioneschu (Studi Kasus: Kaligarang Semarang). Jurnal Presipitasi, 7(2):77-82.

Saragih, S.A. 2008. Pembuatan dan Karakterisasi Karbon Aktif dari Batubara Riau Sebagai Adsorben. Program Pasca Sarjana Bidang IImu Teknik Fakultas Teknik Universitas Indonesia Jakarta.

Sukardjo. 1992. Kimia Koordinasi. Rineka Cipta, Jakarta.

Supriharyono, 2002, Pelestarian dan Pengelolaan Sumber Daya Alam di Wilayah Pesisir Tropis, Hal 156. Gramedia Pustaka Utama: Jakarta.

Suryono, C.A., \& Rochaddi. 2017. Kualitas Perairan di Daerah Fishing Ground Nelayan Kerang Di Pesisir Timur Kota Semarang. Jurnal Kelautan Tropis. 20(1):42-47.

Wahyudianto, F.E. 2016. Studi Pemanfaatan Limbah Cangkang Kerang Darah (Anadara Granosa) sebagai Adsorben $\mathrm{Pb}^{2+}, \mathrm{Cu}^{2+}$, dan $\mathrm{Zn}^{2+}$. Magister Teknik Lingkungan, Institut Teknologi Sepuluh November. Bogor.

WHO (World Health Organization). 1988. Environmental Health Criteria 61: Chromium.

Winarno, F.G., 2004. Kimia Pangan dan Gizi. Cetakan Keempat. Penerbit PT Gramedia Pustaka Utama. Jakarta. hal $50-63$

Yulianto, B., Suwarno, D. Amri, K. Oetari, S. Ridho, A \& Widianarko, B. 2006. Penelitian Tingkat Pencemaran Logam Berat Di Pantai Utara Jawa Tengah. Badan penelitian dan Pengembangan Jawa Tengah, $138 \mathrm{hlm}$.

Yuliusman, Y. \& Adelina PW, A.P., 2010. Pemanfaatan Kitosan dari Cangkang Rajungan pada Proses Adsorpsi Logam Nikel dari Larutan $\mathrm{NiSO}_{4}$. Teknik Kimia Undip. Semarang.

Zustriani, A.K., 2019. Pengaruh Aktivasi Adsorben Biji Pepaya Terhadap Adsorpsiion Logam Besi (Fe) Dan Tembaga (Cu) Dalam Air Limbah. Integrated Lab Journal, 7(1):29-43. 